\title{
Inconel Alloy 690-A New Corrosion Resistant Material*
}

\author{
A. J. Sedriks**, J. W. Schultz** and M. A. Cordovi*** \\ **Inco Research \& Development Center \\ *** Inco Limited
}

\begin{abstract}
INCONEL Alloy 690 (Ni-30Cr-9Fe-0.02C, wt.\%), is a new high-chromium nickel-base alloy, designed to provide a stable austenitic structure combined with resistance to corrosion and oxidation in aggressive industrial environments at elevated temperatures. Extensive laboratory evaluation of Alloy 690 during the past 12 years has demonstrated remarkable resistance to sensitization, and to stress corrosive cracking in chloride environments. In high temperature water, this material resists stress corrosion attack over a wide range of tepmeratures, oxygen contents in the presence of crevices, and lead contamination. Alloy 690 has been found to release only a negligible amount of material when exposed to high velocity water at elevated temperatures-a fact that may be of major importance in light water reactor technology.
\end{abstract}

\section{Introduction}

INCONEL ${ }^{\circledR}$ alloy 690 is a new austenitic nickel-base alloy that was developed to provide excellent corrosion resistance in many demanding high temperature environments. In particular, it shows promise for applications involving high temperature water (e.g., nuclear steam generators) and nitric acid environments (e.g., pickling and nuclear fuel reprocessing).

Preliminary results were presented in a paper by Copson et al. at The Fifth International Congress on Metallic Corrosion in Tokyo, May, 1972 (See page 376 of proceedings).

Alloy 690 is now in full-scale production and has been fabricated into many forms, including sheet, plate, bar, pipe, tube-shells and thin-wall tubing.

This paper brings together some of the available data on the corrosion characteristics of alloy 690 . It also provides a brief description of its physical metallurgy and mechanical properties.

\section{Structure and Properties}

Alloy 690 is a single phase austenitic alloy with a nominal composition of $60 \% \mathrm{Ni}-30 \% \mathrm{Cr}-9 \%$ $\mathrm{Fe}-0.02 \% \mathrm{C}$. This composition places it well within the austenite $(\gamma)$ field at $816^{\circ} \mathrm{C}^{* * * * *}$, as shown in Figure 1. The $\alpha^{\prime}$ phase identified in Figure 1 is a chromium-rich phase, very similar to

* Presented at Meeting of Stress Corrosion Committee, Japan Society of Corrosion Engineers, April 28, 1978

** Suffern, N.Y. U.S.A

*** New York, N.Y. U.S.A.

$* * * * 816^{\circ} \mathrm{C}$ is the lowest temperature at which the $\gamma / \gamma+\alpha^{\prime}$ solvus has been determined (1).

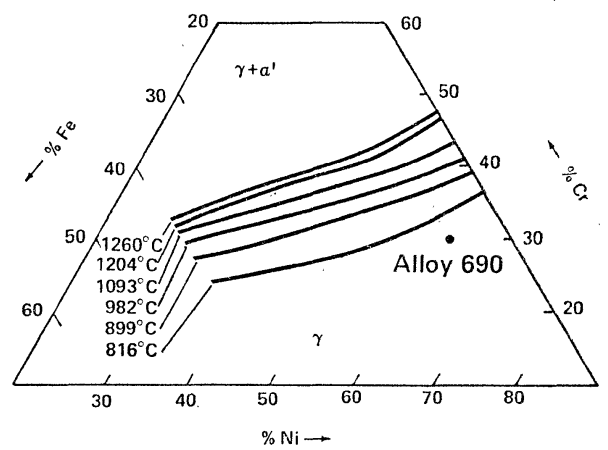

Fig. 1. The $\mathrm{Ni}-\mathrm{Cr}-\mathrm{Fe}$ phase diagram showing the location of the $r / \gamma+\alpha^{\prime}$ solvus from $816^{\circ} \sim 1260^{\circ} \mathrm{C}$.

Table 1. Effect of high temperature exposure on the impact resistance of mill annealed alloy 690

\begin{tabular}{lc}
\hline Exposure & $\begin{array}{c}\text { Room temperature } \\
\text { impact resistance } \\
\text { CVN (Joules) }\end{array}$ \\
\hline None & 189 \\
$12,000 \mathrm{~h} / 566^{\circ} \mathrm{C}$ & 164 \\
$13,248 \mathrm{~h} / 593^{\circ} \mathrm{C}$ & 169 \\
$12,000 \mathrm{~h} / 649^{\circ} \mathrm{C}$ & 172 \\
$12,000 \mathrm{~h} / 760^{\circ} \mathrm{C}$ & 184 \\
\hline
\end{tabular}

the iron-chromium $\sigma$ phase both in morphology and hardness. It can cause embrittlement when precipitated during prolonged high temperature exposure in alloys whose compositions lie in the $\gamma+\alpha^{\prime}$ field. Since the composition of alloy 690 lies well away from the $\gamma+\alpha^{\prime}$ field, precipitation of the embrittling $\alpha^{\prime}$ would not be expected. This is confirmed by the impact properties listed in Table 
1. These data show that the toughness of alloy 690 is virtually unaffected by 12,000 hour exposures at temperature in the range $566 \sim 760^{\circ} \mathrm{C}$. It should be noted that impact resistance is particularly sensitive to precipitation of hard and brittle phases such as $\alpha^{\prime}$ and $\sigma$. For example, room temperature impact resistance for Type 310 stainless steel can drop from $\sim 270 \mathrm{~J}$ to less than $14 \mathrm{~J}$ due to the formation of $\sigma$ phase at $\sim 700^{\circ} \mathrm{C}$.

Carbide precipitation can take place in alloy 690 provided the carbon content is high enough. The carbide in alloy 690 is $\mathrm{Cr}_{23} \mathrm{C}_{6}$. Although carbon solubility has yet to be totally defined, experience indicates that heating to $1150^{\circ} \mathrm{C}$ will dissolve all the carbide in a $0.04 \% \mathrm{C}$ material. As a result, sensitization due to chromium depletion is possible on slow cooling. However, if the carbon content is kept at $0.02 \%$ or below, alloy 690 cannot be sensitized to the Huey test. Also, levels of $0.02 \%$ $\mathrm{C}$ can be readily achieved with the argon-oxygen decarburization process used in the refining of alloy 690 .

The fully austenitic structure of alloy 690 means that it can be fabricated by the same mill practices used to hot and cold work other commercial highnickel alloys such as INCONEL ${ }^{\circledR}$ alloy 600 . Because of its higher chromium content, alloy 690 work hardens slightly more than alloy 600 , as shown in Figure 2. However, this presents no problems in producing heavily worked products such as sheet and thin-wall tubing. The effect of cold work on the room temperature mechanical properties of alloy 690 is shown in Figure 3. Both the strength and ductility respond as expected to

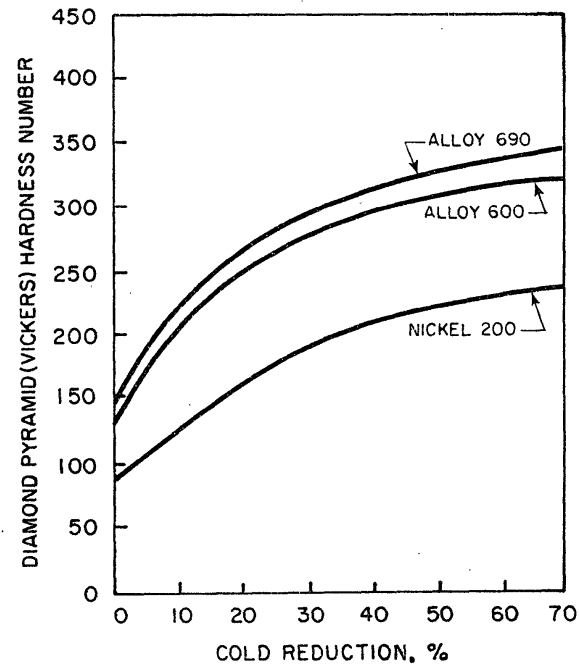

Fig. 2. Work-hardening Alloy 690, Alloy 600 and Nickel 200.

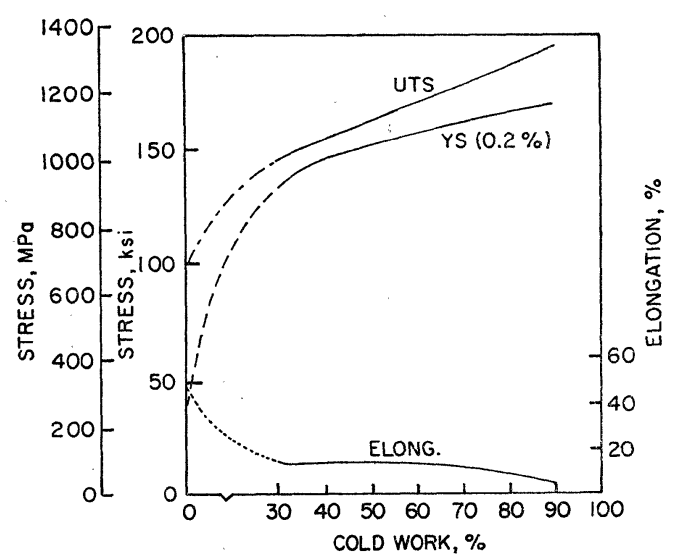

Fig. 3. Effect of cold work on Tensile properties of $12.7 \mathrm{~mm}$ hot rolled plate, annealed at $1205^{\circ} \mathrm{C} / 1 \mathrm{~h} / \mathrm{WQ}$.

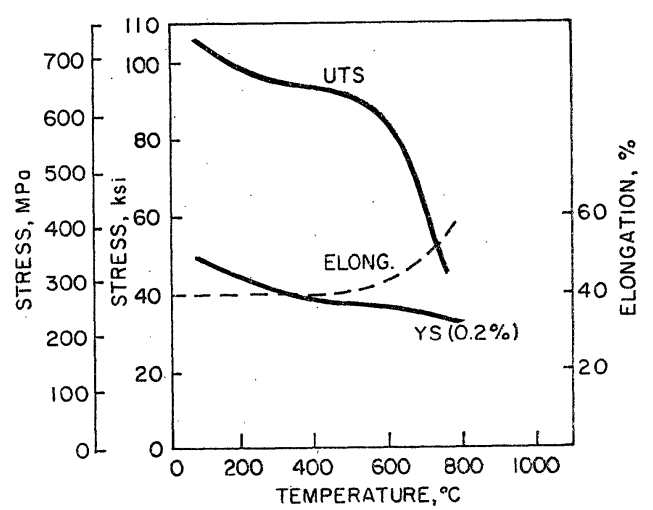

Fig. 4. Short-time elevated temperature Tensile properties of $3.8 \mathrm{~mm}$ cold rolled strip, annealed at $1038^{\circ} \mathrm{C}$.

increasing cold work.

Increasing the tensile test temperature decreases the tentile and yield strengths (Figure 4); however, temperatures in excess of $600^{\circ} \mathrm{C}$ are needed to cause a significant decrease in strength. At steam generator temperatures of $\sim 316^{\circ} \mathrm{C}$, alloy $690 \mathrm{ex}$ hibits high strength properties which are insensitive to changes in temperature in this region. A detailed description of creep and stress-rupture properties for alloy 690, is given in Reference 2.

Regarding welding, alloy 690 can be joined using alloy 600 welding products; also a filler of matching composition has been developed for gas tungsten-arc and gas metal-arc welding, as well as a covered electrode. These can be made commercially available when demand warrants it. There is no evidence of any impairment of stress corrosion resistance due to welding with gas tungsten-arc welds prepared with a matching filler. 
Table 2. Environments used to evaluate the corrosion behavior of Alloy 690

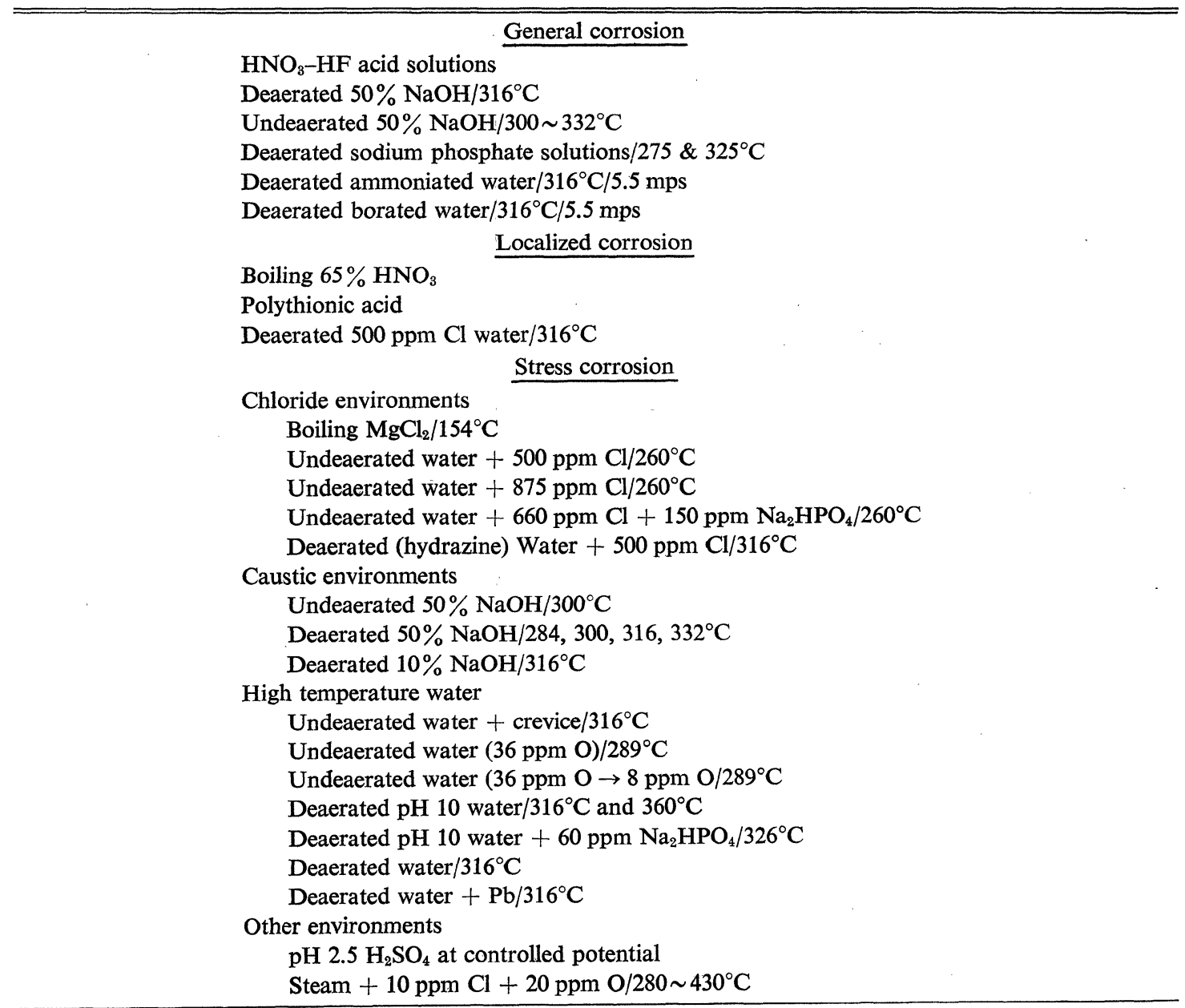

Table 3. Composition of Alloy 690 heats used in corrosion studies

\begin{tabular}{lcccc}
\hline & \multicolumn{4}{c}{ Chemical composition (wt. \%) } \\
\cline { 2 - 5 } & C & Cr & Fe & Ni \\
\hline Commercial heats & & & & \\
Y24A7L & 0.02 & 29.9 & 8.7 & Bal \\
NX10C1H & 0.03 & 30.8 & 9.6 & $"$ \\
NX4458H & 0.01 & 27.9 & 8.8 & $" \prime$ \\
NX20C4H & 0.02 & 30.2 & 9.0 & $" \prime$ \\
NX4460H & 0.06 & 28.3 & 8.9 & $"$ \\
Laboratory heats & & & & \\
T-57177 & 0.05 & 29.3 & 10.1 & Bal \\
T-99016 & 0.07 & 29.3 & 11.4 & $"$ \\
T-53176 & 0.07 & 28.8 & 12.4 & $" \prime$ \\
T-53838 & 0.07 & 28.3 & 12.1 & $" \prime$ \\
T-61540 (Filler) & 0.06 & 29.3 & 11.7 & Bal \\
\hline
\end{tabular}

\section{General Corrosion}

As indicated in Table 2, the corrosion resistance of alloy 690 has been evaluated in a number of
Table 4. Corrosion rates of Alloy 690 in various nitric-hydrofluoric acid mixtures

\begin{tabular}{lcc}
\hline \multirow{2}{*}{ Solution } & \multicolumn{2}{c}{ Corrosion rate* } \\
\cline { 2 - 3 }$\left(\mathrm{g} /\left(\mathrm{m}^{2} . \mathrm{d}\right)\right)$ & $(\mathrm{mm} / \mathrm{yr})$ \\
\hline $10 \% \mathrm{HNO}_{3}+3 \% \mathrm{HF}$ & 3.3 & 0.15 \\
$15 \% \mathrm{HNO}_{3}+3 \% \mathrm{HF}$ & 5.6 & 0.25 \\
$20 \% \mathrm{HNO}_{3}+3 \% \mathrm{HF}$ & 3.3 & 0.15 \\
\hline$* \quad$ Average for duplicate specimens tested at $60^{\circ} \mathrm{C}$. \\
enviroments known to cause general, localized or \\
stress corrosion attack in other alloys. The com- \\
positions of alloy 690 which were investigated are \\
listed in Table 3.
\end{tabular}

\section{1. $\mathrm{HNO}_{3}-\mathrm{HF}$ Acid Solutions}

The reason for testing in mixed nitric-hydrofluoric acids was to evaluate the potential of alloy 690 as a vessel material for processing spent nuclear fuel elements as well as for the tanks of pickling baths. Because of its high chromium con- 


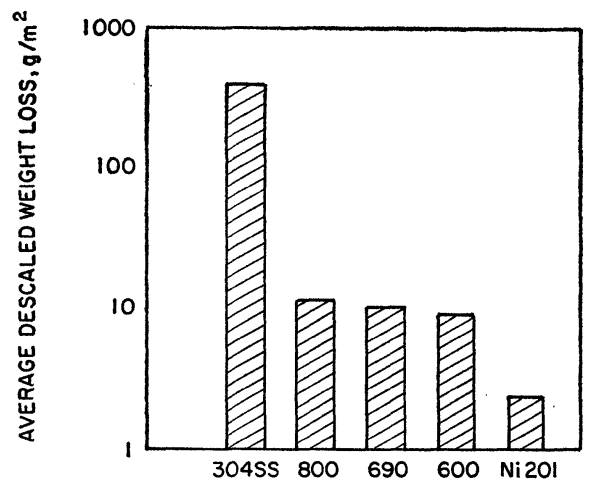

Fig. 5. Descaled weight loss after 2-week exposure to deaerated $50 \% \mathrm{NaOH}$ at $316^{\circ} \mathrm{C}$ (duplicate specimens, Alloy 690 from heat NX10C1H).

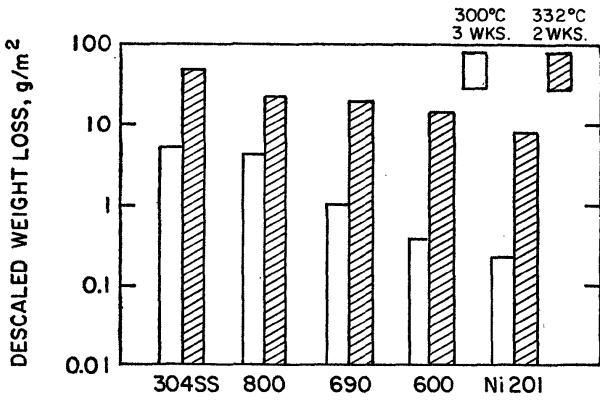

Fig. 6. Descaled weight loss after exposure to undeaerated $50 \% \mathrm{NaOH}$ (single specimens, Alloy 690 from heat Y24A7L).

tent, the alloy exhibits excellent resistance to various nitric-hydrofluoric acid mixtures, as shown in Table 4.

\subsection{Deaerated $50 \% \mathrm{NaOH}$ at $316^{\circ} \mathrm{C}$}

Testing in high temperature $50 \% \mathrm{NaOH}$ environments helped to establish the corrosion resistance of alloy 690 under conditions simulating the most severe superheating imaginable on the secondary side of pressurized water reactor (PWR) steam generators. When the temperature of a layer of water at a heat transfer surface exceeds the temperature of the main body of slightly alkaline water by a temperature difference $\Delta T$, a high concentration of $\mathrm{NaOH}$ can develop in this layer $^{3)}$. The maximum $\Delta T$ attainable on the secondary side of PWR steam generators is not known. The $50 \% \mathrm{NaOH}$ level selected for testing is equivalent to a $\Delta T$ of some $27^{\circ} \mathrm{C}\left(80^{\circ} \mathrm{F}\right)$, which may be higher than that encountered in practice. The $50 \% \mathrm{NaOH}$ test data, both with regard to general corrosion and stress corrosion cracking, must therefore be regarded as representing a theoretical extreme.

The descaled weight loss of alloy 690 and a number of other alloys after exposure in deaerated $50 \%$ $\mathrm{NaOH}$ at $316^{\circ} \mathrm{C}$ is shown in Figure 5. The corrosion scales were removed using the alkaline permanganate-acid method ${ }^{4}$. The results, which are plotted on a logarithmic scale, show that alloy 690 exhibits a corrosion rate intermediate between that of alloy 800 and alloy 600 .

3.3. Undeaerated $50 \% \mathrm{NaOH}$ at $300^{\circ}$ and $332^{\circ} \mathrm{C}$

Descaled weight loss resulting from exposure of the same alloys to undeaerated $50 \% \mathrm{NaOH}$ at $300^{\circ}$ and $332^{\circ} \mathrm{C}$ is shown in Figure 6. For these specimens, the weight loss was determined using the electrolytic-sulfuric acid descaling method ${ }^{4}$.

Again, the results show that alloy 690 exhibits a corrosion rate between that of alloy 800 and alloy 600 .

\subsection{Deaerated Sodium Phosphate Solutions at $275^{\circ}$ and $325^{\circ} \mathrm{C}$}

Corrosion test results of alloy 690 and other alloys in high temperature sodium phosphate solutions have been recently published by Pessal et $a .^{5)}$ and

Table 5. Corrosion of various alloys in high temperature sodium phosphate solutions

\begin{tabular}{lcccrrrr}
\hline \hline & \multicolumn{2}{c}{ Test environment } & & \multicolumn{4}{c}{$\begin{array}{c}\text { Descaled weight loss } \\
\left(\mathrm{mg} / \mathrm{dm}^{2} \text { in 1 yr) }\right.\end{array}$} \\
\hline $\mathrm{Na} / \mathrm{P}$ & $\begin{array}{c}\text { Concentration } \\
(\text { Molality) }\end{array}$ & $\begin{array}{c}\text { Temp. } \\
\left({ }^{\circ} \mathrm{C}\right)\end{array}$ & $\begin{array}{c}\text { Maximum } \\
\text { exposure } \\
\text { time }(\mathrm{h})\end{array}$ & $\begin{array}{c}\text { Alloy } \\
600\end{array}$ & $\begin{array}{c}\text { Alloy } \\
690\end{array}$ & $\begin{array}{c}\text { Alloy } \\
800\end{array}$ & $304 \mathrm{SS}$ \\
\hline 1.35 & 6.0 & 325 & 315 & 680 & 1600 & 620 & 2139 \\
1.6 & 6.0 & 325 & 480 & 2800 & 5600 & 6400 & 5989 \\
2.0 & 5.0 & 325 & 504 & 510 & 600 & 600 & 599 \\
2.2 & 0.18 & 325 & 504 & 86 & 43 & 43 & 257 \\
2.3 & 5.0 & 325 & 451 & 470 & 471 & 1200 & 11123 \\
1.6 & 6.0 & 275 & 1344 & 2400 & - & - & 3000 \\
2.3 & 5.0 & 275 & 1226 & 86 & 150 & 260 & - \\
2.3 & 0.4 & 275 & 1560 & 540 & - & 340 & - \\
2.6 & 0.15 & 275 & 1176 & 43 & 1000 & 100 & - \\
\hline
\end{tabular}


Table 6. High velocity loop test parameters

\begin{tabular}{lll}
\hline \hline \multicolumn{1}{c}{ Parameter } & \multicolumn{1}{c}{ Borated water } & \multicolumn{1}{c}{ Ammoniated water } \\
\hline Temperature & $316^{\circ} \mathrm{C}$ & $316^{\circ} \mathrm{C}$ \\
Pressure & $13.8 \mathrm{MPa}(2000 \mathrm{psig})$ & $13.8 \mathrm{MPa}(2000 \mathrm{psig})$ \\
Flow Rate & $5.5 \mathrm{~m} / \mathrm{s}(18 \mathrm{ft} / \mathrm{s})$ & $5.5 \mathrm{~m} / \mathrm{s}(18 \mathrm{ft} / \mathrm{s})$ \\
Hydrogen & $25 \mathrm{cc}\left(\mathrm{STP} / \mathrm{kg} \mathrm{H} \mathrm{H}_{2} \mathrm{O}\right)$ & $25 \mathrm{cc}\left(\mathrm{STP} / \mathrm{kg} \mathrm{H} \mathrm{H}_{2} \mathrm{O}\right)$ \\
Oxygen & $0 \sim 15 \mathrm{ppb}$ & $0 \sim 15 \mathrm{ppb}$ \\
Boron $\left(\mathrm{H}_{3} \mathrm{BO}_{3}\right)$ & $1500 \mathrm{ppm}$ & \\
Lithium $(\mathrm{LiOH})$ & $0.7 \mathrm{ppm}$ & \\
pH & 5.5 & $9.5 \sim 10.9^{*}$ \\
Volume of Loop & $32.3 l(8.5 \mathrm{gal})$ & $32.3 l(8.5 \mathrm{gal})$ \\
\hline
\end{tabular}

* Adjusted with ammonia.

are reproduced in part in Table 5. The extent of attack on the various alloys is dependent on the phosphate concentration and the $\mathrm{Na} / \mathrm{P}$ ratios, with the higher nickel alloys generally exhibiting greater resistance to attack than Type 304 stainless steel.

\subsection{Deaerated Ammoniated and Borated Water at $316^{\circ} \mathrm{C}$}

In pressurized water reactors, a factor of particular interest is the corrosion resistance of steam generator tubing materials in flowing primary water. Material lost to the stream can become radioactive by coming in contact with the reactor core and then redeposit on the primary circuit surfaces. A recent evaluation of the corrosion behavior of alloy 600 and alloy 800 in a CANDU reactor outlet autoclave during pressurized lithiated operation has shown that these two alloys exhibit comparable corrosion resistance ${ }^{6}$. The corrosion resistance of alloy 690 under these and similar primary coolant conditions is not known. In an attempt to obtain some insight into how alloy 690 is likely to behave, a laboratory test program was carried out employing a high velocity test loop. Alloy 690 was evaluated in two simulated primary water environments, referred to here as "ammoniated" and "borated". The test parameters in these environments are shown in Table 6.

The alloy 690 test specimens and those of control materials were heat treated for $0.5 \mathrm{~h}$ at $980^{\circ} \mathrm{C} /$ AC. The surfaces were prepared by grinding on a wet 120 grit silicon carbide belt to a $0.75 \mu \mathrm{m}$ finish. The specimens were weighed and then exposed for extended periods of time under the conditions shown in Table 6. After exposure, the specimens from the ammoniated water tests were descaled by cathodic charging in $5 \% \mathrm{H}_{2} \mathrm{SO}_{4}$ inhibited with quinoline ethiodide ${ }^{4)}$. The specimens from the borated water tests were descaled by the alkaline permanganate acid method ${ }^{4}$. The method of reporting results and terminology adopted are defined in NACE standard TM-02-74, covering the following terms:

1. "Descaled metal loss" (metal consumed): The difference between initial weight and weight after removal of adherent corrosion film.

2. "Corrosion film weight" (adherent corro" sion film): The difference between the weight before descaling and the weight after descaling.

The difference between the descaled metal loss and the corrosion film weight represents material
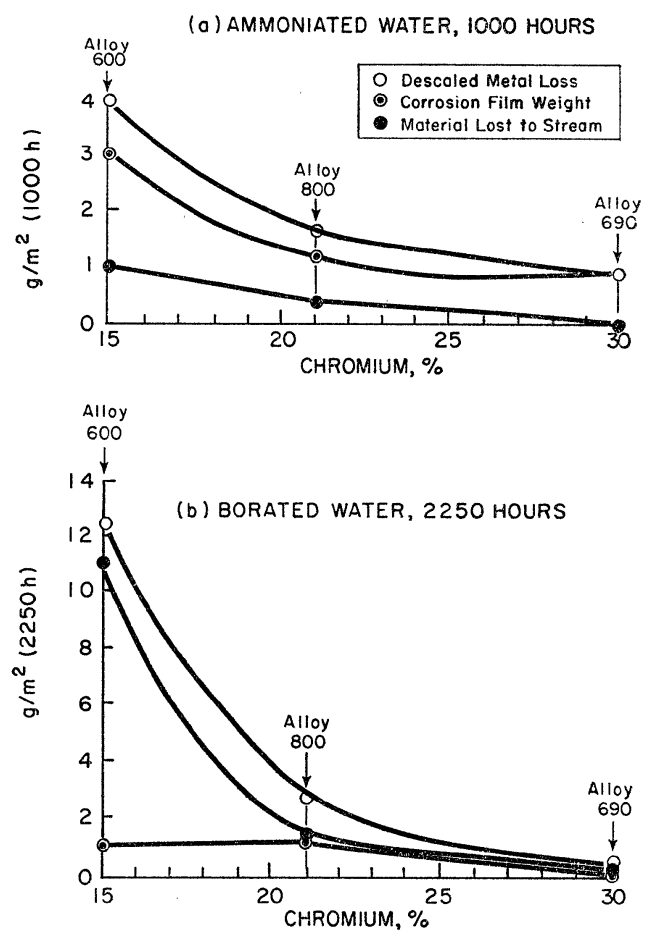

Fig. 7. Effect of chromium content on material lost to stream in $316^{\circ} \mathrm{C}$ deaerated water flowing at a velocity of $5.5 \mathrm{~m} / \mathrm{s}$. Alloy 690 from Heat Y24A7L. 
lost to the stream. Alloys showing the least loss of material to the stream would be expected to produce less activity on the primary water side of steam generators.

The behavior of alloy 690 in ammoniated and borated water is shown in Figure 7. It can be seen that alloy 690 loses less material to the stream than any of the other materials tested. The films formed on alloy 690 as a result of the ammoniated and borated water exposures were of the thin tarnish type and appeared to be extremely adherent to the metal.

The results suggest that the crud release rates of alloy 690 in an operating steam generator could be very low. The use of this alloy in steam generators could therefore reduce the amount of activity built up on the primary side. This is assuming that an important source of the active species is the material being corroded from the tube wall. A note of caution is warranted here; the data shown in Figure 7 are subject to a standard error of about $25 \%$ and should be regarded as a guide rather than a precise measurement.

\section{Localized Corrosion}

\subsection{Intergranular Corrosion Tests in Boiling $65 \% \mathrm{HNO}_{3}$}

The intergranular corrosion resistance of alloy 690 was evaluated in boiling $65 \% \mathrm{HNO}_{3}$. This test, known as the Huey test, is standardized as ASTM A262, Practice C. It is a very severe test which for stainless steels attacks chromium depleted areas, carbides, and $\sigma$, when present.

The intergranular corrosion resistance of alloy
690 determined by the Huey test was found to be critically dependent on the carbon content of the alloy. As shown in Figure 8, alloy 690 containing $0.02 \% \mathrm{C}$ shows very low corrosion rates in boiling

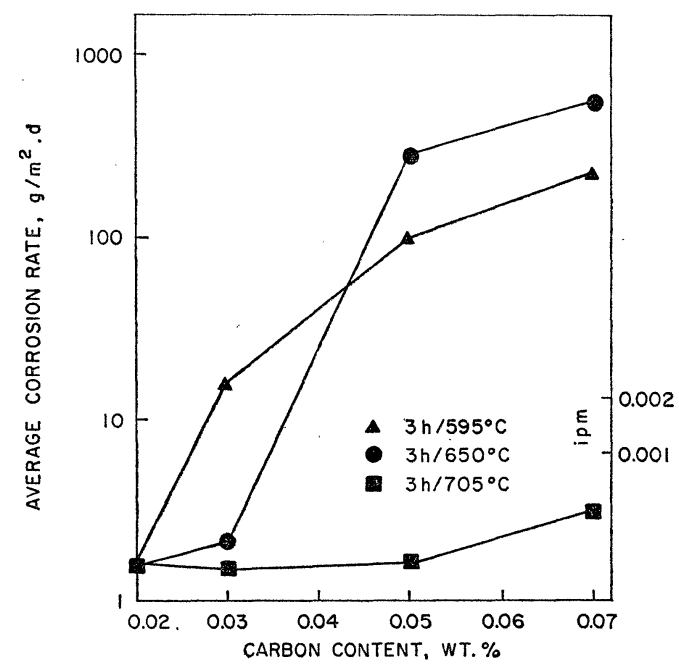

Fig. 8. The effect of carbon content on the corrosion rate of Alloy 690 in the huey test. Material annealed $1 \mathrm{~h} / 1150^{\circ} \mathrm{C} / \mathrm{WQ}$ before sensitizing.

Table 7. Corrosion rates of Alloy 690 welded with matching filler in boiling $65 \%$ nitric acid

\begin{tabular}{cccc}
\hline \multirow{2}{*}{ Heat No. } & \multirow{2}{*}{$\%$} & \multicolumn{2}{c}{ Corrosion rate } \\
\cline { 3 - 4 } & & $\left(\mathrm{g} / \mathrm{m}^{2} . \mathrm{d}\right)$ & $(\mathrm{ipm})$ \\
\hline NX20C4H & 0.02 & 2 & 0.0003 \\
NX10C1H & 0.03 & 2 & 0.0003 \\
\hline
\end{tabular}

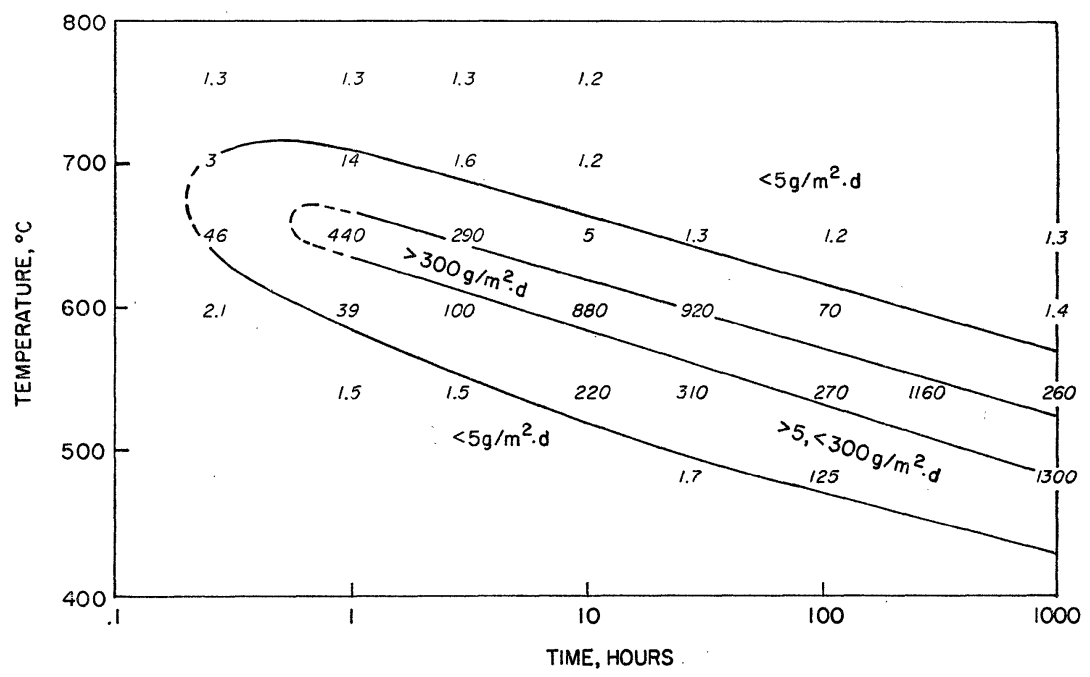

Fig. 9. Time-temperature-sensitization diagran for Alloy 690 in boiling $65 \%$ Nitric acid. Heat T-57177 containing $0.05 \% \mathrm{c}$, solution annealed $1 \mathrm{~h} / 1150^{\circ} \mathrm{C} / \mathrm{WQ}$. 
Table 8. Polythionic acid and nitric acid test results

\begin{tabular}{|c|c|c|c|c|}
\hline \multirow{2}{*}{ Alloy } & \multirow{2}{*}{ Heat treatment } & \multirow{2}{*}{$\begin{array}{c}\text { Polythionic acid test }^{\mathrm{a})} \\
\begin{array}{c}\text { No. of specimens } \\
\text { cracked/number } \\
\text { destruclively examined }\end{array}\end{array}$} & \multicolumn{2}{|c|}{$\begin{array}{l}\text { Corrosion rateb) in } \\
\text { boiling } 65 \% \mathrm{HNO}_{3}\end{array}$} \\
\hline & & & $\left(g /\left(m^{2} \cdot d\right)\right)$ & $(\mathrm{mm} / \mathrm{yr})$ \\
\hline \multirow[t]{4}{*}{$690^{*}$} & $0.5 \mathrm{~h} @ 1038^{\circ} \mathrm{C} / \mathrm{AC}$ & $0 / 2$ & 3.3 & 0.15 \\
\hline & $0.5 \mathrm{~h} @ 1038^{\circ} \mathrm{C} / \mathrm{AC}$ & & & \\
\hline & $+100 \mathrm{~h} @ 316^{\circ} \mathrm{C} / \mathrm{AC}$ & $0 / 2$ & 2.0 & 0.09 \\
\hline & $0.5 \mathrm{~h} @ 1038^{\circ} \mathrm{C} / \mathrm{AC}$ & & & \\
\hline & $+1000 \mathrm{~h} @ 316^{\circ} \mathrm{C} / \mathrm{AC}$ & $0 / 2$ & 3.3 & 0.15 \\
\hline \multirow[t]{2}{*}{ 304SS } & $1 \mathrm{~h} @ 1065^{\circ} \mathrm{C} / \mathrm{WQ}$ & & & \\
\hline & $+2 \mathrm{~h} @ 675^{\circ} \mathrm{C} / \mathrm{AC}$ & $1 / 1^{c)}$ & - & - \\
\hline
\end{tabular}

a) Test duration $=720 \mathrm{~h}$; u-bend test specimens

b) Average of five 48-h periods

c) Cracks within $1 \mathrm{~h}$, qualifying test

* Heat Y24A7L

$65 \% \mathrm{HNO}_{3}$, irrespective of heat treatment. For the 0.02 and $0.03 \% \mathrm{C}$ alloys, the corrosion rates represent the average values of five consecutive 48hour exposures, whereas for the 0.05 and $0.07 \% \mathrm{C}$ alloys, the weight loss is an average of two 48-hour exposure periods. The extremely low corrosion rate of the $0.02 \% \mathrm{C}$ alloy, together with the fact that no detectable intergranular attack could be detected by conventional metallographic examination of sections after corrosion testing, suggest that the $0.02 \% \mathrm{C}$ alloy is resistant to sensitization.

Alloy 690 containing 0.02 and $0.03 \% \mathrm{C}$ was also examined in the welded condition. Test coupons, $0.5 \mathrm{~cm}$ thick, were butt welded using the matching filler and exposed for five 48-hour test periods to boiling $65 \% \mathrm{HNO}_{3}$. Again, as shown in Table 7, very low rates of corrosion were found, with the only attack observed being light interdendritic etching of the matching filler.

Higher carbon versions (e.g., $0.05 \% \mathrm{C}$ ) of alloy 690 can be furnace sensitized to give significant intergranular attack in boiling nitric acid, as shown in the time-temperature-sensitization diagram in Figure 9. Effects of welding on the sensitization behavior of such higher carbon materials still need to be evaluated.

\subsection{Polythionic Acid Tests}

In conjunction with the boiling nitric acid tests, alloy 690 was also evaluated for resistance to polythionic acid cracking. The standard polythionic acid test was employed, with the potency of the acid solution being demonstrated by cracking a sensitized type 304 stainless steel within 1 hour. Alloy 690 exhibited complete resistance to cracking in this solution, both in the annealed condition and after prolonged aging at $316^{\circ} \mathrm{C}$ (Table 8).

\subsection{Pitting Tests in Chloride Solutions}

Alloy 690 specimens from heats $\mathrm{NX} 10 \mathrm{C} 1 \mathrm{H}$, $\mathrm{NX} 4460 \mathrm{H}$, and NX4458H (see Table 3) were exposed for 96 weeks at $316^{\circ} \mathrm{C}$ in water containing $500 \mathrm{ppm}$ chloride, and deaerated with $\mathrm{N}_{2} \mathrm{H}_{4}$, to determine whether pitting would occur. No evidence of pitting or any other type of attack was found using optical and scanning electron microscopes at magnifications up to $3000 \mathrm{X}$.

\section{Stress Corrosion Cracking}

\subsection{Chloride Environments}

Alloy 690 has been tested for resistance to chloride stress corrosion cracking in a wide variety of high temperature chloride environments. The controls used in these tests were alloy 800 and Type 304 stainless steel. Both of these alloys are known to crack in elevated temperature chloride environments, with alloy 800 being more resistant than Type 304 stainless steel. In all cases, alloy 690 was tested for periods significantly in excess of those required to crack alloy 800 . The following tests were employed:

1. Boiling $\mathrm{MgCl}_{2}, 154^{\circ} \mathrm{C}, 13.9$ weeks.

2. Undeaerated water $+500 \mathrm{ppm}$ chloride $(\mathrm{NaCl}), 260^{\circ} \mathrm{C}, 18$ weeks.

3. Vapor phase above environment No. 2, 8 weeks.

4. Undeaerated water $+875 \mathrm{ppm}$ chloride $(\mathrm{NaCl}), 260^{\circ} \mathrm{C}, 8$ weeks.

5. Vapor phase above environment No. 4,8 weeks.

6. Undeaerated water $+660 \mathrm{ppm}$ chloride $(\mathrm{NaCl})+150 \mathrm{ppm} \quad \mathrm{Na}_{2} \mathrm{HPO}_{4}, 260^{\circ} \mathrm{C}, 8$ weeks.

7. Deaerated $\mathrm{N}_{2} \mathrm{H}_{4}$ water +500 ppm chlo- 
Table 9. Stress corrosion tests at $260^{\circ} \mathrm{C}$ in undeaerated water containing 500 ppm chloride $(\mathrm{NaCl})$ to evaluate the effects of heat treatment, cold work, welding and crevices

\begin{tabular}{|c|c|c|c|c|c|}
\hline Alloy & $\begin{array}{l}\text { Heat treatment } \\
\text { code }\end{array}$ & $\begin{array}{l}\text { Number of } \\
\text { specimens } \\
\text { (No. of } \\
\text { heats) }\end{array}$ & $\begin{array}{c}\text { Test } \\
\text { duration } \\
\text { (weeks) }\end{array}$ & $\begin{array}{l}\text { Number of } \\
\text { specimens } \\
\text { cracked/number } \\
\text { destructively } \\
\text { examined }\end{array}$ & $\begin{array}{c}\text { Maximum } \\
\text { depth of } \\
\text { attack } \\
(\mathrm{mm})\end{array}$ \\
\hline \multirow[t]{8}{*}{$690 *$} & MA & $2(1)$ & 18 & $0 / 2$ & 0 \\
\hline & $\mathrm{MA}+\mathrm{L}$ & $2(1)$ & 18 & $0 / 2$ & 0 \\
\hline & $\mathbf{M A}+\mathrm{A}_{1}$ & $2(1)$ & 18 & $0 / 2$ & 0 \\
\hline & $\mathrm{MA}+\mathrm{CR}$ & $2(1)$ & 18 & $0 / 2$ & 0 \\
\hline & $A_{1}+L$ & $2(1)$ & 18 & $0 / 2$ & 0 \\
\hline & $\mathrm{A}_{3}+\mathrm{L}$ & $2(1)$ & 18 & $0 / 2$ & 0 \\
\hline & $A_{2}+W(12.7)$ & $2(1)$ & 8 & $0 / 2$ & 0 \\
\hline & $\mathrm{A}_{2}+\mathrm{W}(25.4)$ & $2(1)$ & 8 & $0 / 2$ & 0 \\
\hline 800 & $\mathrm{~A}_{4}+\mathrm{L}_{0}$ & $2(1)$ & 1 & $2 / 2$ & 2.5 \\
\hline 304 SS & $\mathbf{A}_{4}+\mathbf{L}_{0}$ & $2(1)$ & 1 & $2 / 2$ & 3.0 \\
\hline
\end{tabular}

Double U-bend (crevice) test specimens for alloy 690

Single U-bend test specimens for alloy 800 and 304 SS

Code: $\mathbf{M A}=$ Mill Annealed

$\mathrm{CR}=$ Cold Rolled $40 \%$

$\mathrm{A}_{1}=1 \mathrm{~h} @ 1093^{\circ} \mathrm{C} / \mathrm{WQ}$

$\mathrm{A}_{2}=1 \mathrm{~h} @ 1150^{\circ} \mathrm{C} / \mathrm{WQ}$

$\mathrm{A}_{3}=1 \mathrm{~h} @ 1205^{\circ} \mathrm{C} / \mathrm{WQ}$

$\mathrm{A}_{4}=1 \mathrm{~h} @ 1065^{\circ} \mathrm{C} / \mathrm{WQ}$

$\mathrm{L}_{0}=5 \mathrm{~h} @ 704^{\circ} \mathrm{C} / \mathrm{AC}$

$\mathrm{L}=2 \mathrm{~h} @ 650^{\circ} \mathrm{C} / \mathrm{AC}$

$\mathrm{W}$ (thickness, $\mathrm{mm}$ ) =manual gas tungsten-arc welded at indicated thickness with matching filler

* Heat Y24A7L

ride $(\mathrm{NaCl}), 316^{\circ} \mathrm{C}, 96$ weeks.

In tests using undeaerated water plus chloride or chloride plus phosphate, the solution was prepared by dissolving $\mathrm{NaCl}$ in distilled-deionized water. The $\mathrm{pH}$ was not adjusted and the autoclave was sealed with 1 atmosphere of air in the headspace. The oxygen content of the solution at temperature could not be measured, but was estimated to be at least $6 \mathrm{ppm}$ at the start of each test period. Specimens were either immersed in the solution or suspended in the vapor phase above the solution.

In the test using deaerated water plus chloride, the solution was prepared by dissolving $\mathrm{NaCl}$ in distilled-deionized water to which $65 \% \mathrm{~N}_{2} \mathrm{H}_{4}$ was added $\left(0.2 \mathrm{ml}\right.$ of $\mathrm{N}_{2} \mathrm{H}_{4}$ per $1.6 l$ of solution). The solution was then deaerated within the closed autoclave by three alternate pressurizing ( $3.5 \mathrm{MPa}-$ argon)/aspirating (5.7 $\mathrm{KPa}$ ) cycles, and the autoclave sealed with 1 atmosphere of argon in the headspace. The oxygen content after deaeration was $<20 \mathrm{ppb}$.

Alloy 690 did not exhibit stress corrosion cracking in any of the environments used. Furthermore in Test No. 2 (Table 9), extensive evaluation of the effects of heat treatment, cold work, welding, and the presence of crevices did not reveal any detrimental variable. Since no evidence of any stress corrosion susceptibility was found, alloy 690 must be regarded as highly resistant to chloride cracking.

\subsection{Caustic Environments}

Alloy 690 has been tested for resistance to caustic stress corrosion cracking in both undeaerated and deaerated $\mathrm{NaOH}$ solutions. The controls used in the caustic tests were Type 304 stainless steel, alloy 800, alloy 600 and commercially pure nickel, Nickel 201 . The latter was included when it was realized that all commercially available $\mathrm{Fe}-\mathrm{Cr}-\mathrm{Ni}$ alloys exhibit some degree of cracking in high temperature caustic environments.

The following test environments were employed:

1. Undeaerated $50 \% \mathrm{NaOH}, 300^{\circ} \mathrm{C}$.

2. Deaerated $50 \% \mathrm{NaOH}, 284,300,316$ and $332^{\circ} \mathrm{C}$.

3. Deaerated $10 \% \mathrm{NaOH}, 316^{\circ} \mathrm{C}$.

For these caustic tests, the autoclave solution was prepared by dissolving ACS certified reagent grade electrolytic $\mathrm{NaOH}$ pellets in distilled water. For tests in undeaerated $\mathrm{NaOH}$, the autoclave was sealed with an $0.35 \mathrm{MPa}$ over-pressure of air in 
Table 10. Stress corrosion tests in undeaerated $50 \% \mathrm{NaOH}$ at $300^{\circ} \mathrm{C}$ to evaluate the effects of heat treatment, cold work, and welding

\begin{tabular}{|c|c|c|c|c|c|}
\hline Alloy & $\begin{array}{l}\text { Heat } \\
\text { treatment } \\
\text { code }\end{array}$ & $\begin{array}{l}\text { Number of } \\
\text { specimens } \\
\text { (Number } \\
\text { of heats) }\end{array}$ & $\begin{array}{c}\text { Test } \\
\text { duration } \\
(w k)\end{array}$ & $\begin{array}{l}\text { Number of } \\
\text { specimens } \\
\text { cracked/number } \\
\text { destructively } \\
\text { examined }\end{array}$ & $\begin{array}{l}\text { Maximum } \\
\text { depth of } \\
\text { attack } \\
(\mathrm{mm})\end{array}$ \\
\hline \multirow[t]{9}{*}{$690^{*}$} & MA & $2(1)$ & 3.9 & $0 / 2$ & 0 \\
\hline & $\mathbf{M A}+\mathbf{L}$ & $2(1)$ & 3.9 & $0 / 1$ & 0 \\
\hline & $\mathrm{MA}+\mathrm{A}_{\mathbf{1}}$ & $2(1)$ & 3.9 & $0 / 2$ & 0 \\
\hline & $\mathrm{MA}+\mathrm{CR}$ & $1(1)$ & 1.7 & $1 / 1$ & 2.79 \\
\hline & & $1(1)$ & 3.9 & $0 / 1$ & 0 \\
\hline & $\mathrm{A}_{1}+\mathrm{L}$ & $2(1)$ & 3.9 & $0 / 2$ & 0 \\
\hline & $\mathrm{A}_{3}+\mathrm{L}$ & $2(1)$ & 3.9 & $0 / 2$ & 0 \\
\hline & $A_{2}+W(12.7)$ & $2(1)$ & 3.9 & $0 / 2$ & 0 \\
\hline & $\mathrm{A}_{3}+\mathrm{W}(25.4)$ & $2(1)$ & 3.9 & $0 / 2$ & 0 \\
\hline \multirow[t]{2}{*}{800} & $\mathrm{~A}_{1}+\mathrm{L}$ & $2(1)$ & 1.7 & $2 / 2$ & 1.06 \\
\hline & MA & $2(1)$ & 1.3 & $2 / 2$ & 2.15 \\
\hline \multirow[t]{5}{*}{600} & $\mathrm{CR}+\mathrm{A}_{1}$ & $1(1)$ & 2.6 & $1 / 1$ & 1.06 \\
\hline & & $1(1)$ & 3.9 & $1 / 1$ & 0.06 \\
\hline & $\mathrm{MA}+\mathrm{CR}$ & $2(1)$ & 3.9 & $0 / 2$ & 0 \\
\hline & $\mathbf{A}_{1}+\mathbf{L}$ & $2(1)$ & 3.9 & $2 / 2$ & 0.02 \\
\hline & $A_{3}+L$ & $2(1)$ & 3.9 & $2 / 2$ & 0.06 \\
\hline \multirow[t]{2}{*}{304 SS } & $A_{1}$ & $2(1)$ & 0.4 & $2 / 2$ & 3.05 \\
\hline & $A_{1}+L$ & $1(1)$ & 0.4 & $1 / 1$ & 3.05 \\
\hline 201 & MA & $2(1)$ & 3.9 & $0 / 2$ & 0 \\
\hline
\end{tabular}

U-bend test specimens

Code: $\mathrm{MA}=$ mill annealed

$\mathrm{CR}=$ cold rolled $40 \%$

$\mathrm{A}_{1}=1 \mathrm{~h} @ 1093^{\circ} \mathrm{C} / \mathrm{WQ}$

$\mathrm{A}_{2}=1 \mathrm{~h} @ 1150^{\circ} \mathrm{C} / \mathrm{WQ}$

$\mathrm{A}_{3}=1 \mathrm{~h} @ 1205^{\circ} \mathrm{C} / \mathrm{WQ}$

$\mathrm{L}=2 \mathrm{~h} @ 650^{\circ} \mathrm{C} / \mathrm{AC}$

$\mathrm{W}($ thickness, $\mathrm{mm})=$ manual gas tungsten-arc welded at indicated thickness with matching filler

* Heat Y24A7L

the headspace. The specimens were examined after each 3-day exposure period, with a fresh solution being used for each subsequent period. For tests in deaerated $\mathrm{NaOH}$, deaeration was accomplished by three alternate pressurizing (3.5 $\mathrm{MPa}-$ argon)/aspirating (5.7 $\mathrm{KPa}$ ) cycles, followed by a 2-hour argon bubbling treatment. The autoclave was sealed with 1 atmosphere of argon in the headspace.

The results from the undeaerated $50 \% \mathrm{NaOH}$ tests are shown in Table 10 . With the exception of one of two cold rolled specimens, alloy $690 \mathrm{did}$ not exhibit cracking in the 27-day test period, irrespective of heat treatment, cold work, or presence of welds.

The results from the deaerated $50 \% \mathrm{NaOH}$ tests have been previously reported ${ }^{7,8)}$. At $316^{\circ} \mathrm{C}$, alloy 690 appears to have a slightly lower resistance to stress corrosion cracking than alloy 600 in this environment (see scatterband shown in
Figure 10). However, the differences are small and dependent on test temperature ${ }^{7)}$.

In deaerated $50 \% \mathrm{NaOH}$, alloy 600 appears to be somewhat more resistant to stress corrosion cracking than alloy 690 . The reverse is true in deaerated $10 \% \mathrm{NaOH}$, as shown in Figure 10. Here, with the exception of Nickel 201, alloy 690 was the most resistant alloy tested, although again the difference between alloy 600 and alloy 690 is slight.

The caustic stress corrosion test data can be summarized as indicating that alloy 690 is the most resistant of the alloys tested in undeaerated $50 \%$ $\mathrm{NaOH}$ and deaerated $10 \% \mathrm{NaOH}$, while its resistance is slightly inferior to that of alloy 600 in deaerated $50 \% \mathrm{NaOH}$.

\subsection{High Temperature Water Containing Oxy- gen}

It has been known for a long time ${ }^{9)}$ that most commercially available $\mathrm{Fe}-\mathrm{Cr}-\mathrm{Ni}$ alloys exhibit 


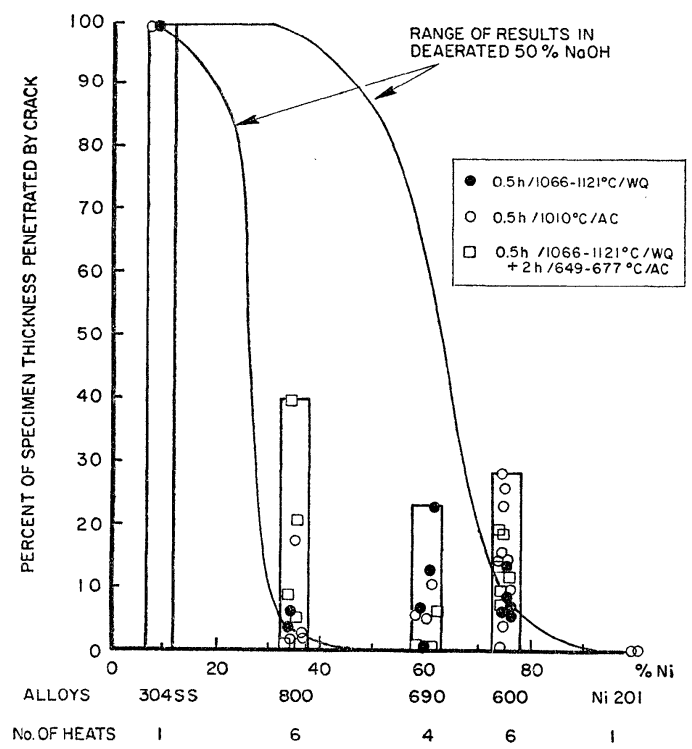

Fig. 10. Stress corrosion cracking of U-bend specimens in deaerated $10 \% \mathrm{NaOH}$ at $316^{\circ} \mathrm{C}$. Exposure time $=6$ weeks. stress corrosion cracking in oxygen-containing (undeaerated) water at elevated temperatures in the presence of a crevice. In fact, stress corrosion resistance under these conditions was a major parameter in the development of the composition of alloy 690. The "oxygen-plus-crevice" test used here employs double U-bend specimens, with the crevice being formed between the inner and outer members of the specimen. Cracking, when it occurs, is confined to the outer surface of the inner $\mathrm{U}$-bend member, having been initiated within the crevice. In these tests, the environment was distilled and deionized water adjusted to $\mathrm{pH} 10$ with $\mathrm{NH}_{4} \mathrm{OH}$. The autoclave was sealed with 1 atmosphere of air in the headspace, which provides a minimum dissolved oxygen content of $6 \mathrm{ppm}$.

As shown in Table 11, cracking was readily obtained in the control alloys, whereas alloy 690 survived the 48-week test period without cracking. The cracking resistance of alloy 690 in this environment was not impaired by various heat treatments, cold work, or the presence of welds.

Table 11. Stress corrosion tests in undeaerated water at $316^{\circ} \mathrm{C}$ to evaluate the role of heat treatment, cold work, and welding on the "oxygen-plus-crevice" effect

\begin{tabular}{llcccc}
\hline \hline Alloy & $\begin{array}{c}\text { Heat } \\
\text { treatment } \\
\text { code }\end{array}$ & $\begin{array}{c}\text { Number of } \\
\text { specimens } \\
\text { (No. of } \\
\text { Heats) }\end{array}$ & $\begin{array}{c}\text { Test } \\
\text { duration } \\
\text { (Weeks) }\end{array}$ & $\begin{array}{c}\text { Number of } \\
\text { specimens } \\
\text { cracked/number } \\
\text { destructively } \\
\text { examined }\end{array}$ & $\begin{array}{c}\text { Maximum } \\
\text { depth of } \\
\text { attack } \\
\text { (mm) }\end{array}$ \\
\hline $690^{*}$ & $\mathrm{MA}$ & $2(1)$ & 48 & $0 / 2$ & 0 \\
& $\mathrm{MA}+\mathrm{L}$ & $2(1)$ & 48 & $0 / 2$ & 0 \\
& $\mathrm{MA}+\mathrm{A}_{1}$ & $2(1)$ & 48 & $0 / 2$ & 0 \\
& $\mathrm{MA}+\mathrm{CR}$ & $2(1)$ & 48 & $0 / 2$ & 0 \\
& $\mathrm{~A}_{1}+\mathrm{L}$ & $2(1)$ & 48 & $0 / 2$ & 0 \\
& $\mathrm{~A}_{3}+\mathrm{L}$ & $2(1)$ & 48 & $0 / 2$ & 0 \\
& $\mathrm{~A}_{2}+\mathrm{W}(12.7)$ & $4(1)$ & 48 & $0 / 4$ & 0 \\
600 & $\mathrm{~A}_{2}+\mathrm{W}(25.4)$ & $2(1)$ & 48 & $0 / 2$ & 0 \\
800 & $\mathrm{MA}+\mathrm{W}(3.8)+\mathrm{L}_{1}$ & $2(1)$ & 48 & $0 / 2$ & 0 \\
$304 \mathrm{SS}$ & $\mathrm{A}_{1}+\mathrm{L}_{2}$ & $2(1)$ & 2 & $2 / 2$ & 2.6 \\
& $\mathrm{~A}_{1}+\mathrm{L}_{2}$ & $2(1)$ & 4 & $2 / 2$ & 2.0 \\
& $\mathrm{~A}_{1}+\mathrm{L}_{2}$ & $2(1)$ & 4 & $2 / 2$ & 3.0 \\
\hline
\end{tabular}

Double U-Bend (crevice) test specimens

Code: $\mathrm{MA}=$ Mill Annealed

$\mathrm{CR}=$ Cold Rolled $40 \%$

$\mathrm{A}_{1}=1 \mathrm{~h} @ 1093^{\circ} \mathrm{C} / \mathrm{WQ}$

$\mathrm{A}_{2}=1 \mathrm{~h} @ 1150^{\circ} \mathrm{C} / \mathrm{WQ}$

$\mathrm{A}_{3}=1 \mathrm{~h} @ 1205^{\circ} \mathrm{C} / \mathrm{WQ}$

$\mathrm{L}=2 \mathrm{~h} @ 650^{\circ} \mathrm{C} / \mathrm{AC}$

$\mathrm{L}_{1}=4 \mathrm{~h} @ 593^{\circ} \mathrm{C} / \mathrm{AC}$

$\mathrm{L}_{2}=5 \mathrm{~h} @ 704^{\circ} \mathrm{C} / \mathrm{AC}$

$\mathrm{W}$ (thickness, $\mathrm{mm}$ ) $=$ manual gas tungsten-arc welded at indicated thickness with matching filler 
Table 12. Stress corrosion tests of Alloy 690 of single and double U-bends in highly oxygenated $289^{\circ} \mathrm{C}$ water

\begin{tabular}{cllcl}
\hline \hline Heat & $\begin{array}{c}\text { Heat treatment } \\
\text { of outer } \\
\text { U-bend member }\end{array}$ & $\begin{array}{c}\text { Heat treatment } \\
\text { of inner } \\
\text { U-bend member }\end{array}$ & $\begin{array}{c}\text { Number of } \\
\text { specimens } \\
\text { cracked/number } \\
\text { destructively } \\
\text { examined }\end{array}$ & Result \\
\hline NX10C1H & A & MA+W (12.7) & $0 / 1$ & No attack \\
& A & MA+W $(12.7)$ & $0 / 1$ & No attack \\
Y24A7L & A +L & None tested & $0 / 2$ & No attack \\
& A & MA+W (12.7) & $0 / 1$ & Weld defect \\
Both & MA & MA+W (12.7) & $0 / 1$ & No attack \\
& MA (Y24A7L) & None tested & $0 / 2$ & No attack \\
& MA (Y24A7L) & MA+CR (NX10ClH) & $0 / 1$ & No attack \\
\hline
\end{tabular}

Code: $\mathrm{MA}=$ Mill annealed

$\mathrm{A}=1 \mathrm{~h} @ 1120^{\circ} \mathrm{C} / \mathrm{WQ}$

$\mathrm{L}=2 \mathrm{~h} @ 675^{\circ} \mathrm{C} / \mathrm{AC}$

$\mathrm{W}$ (thickness, $\mathrm{mm}$ ) $=$ manual gas tungsten-arc welded at indicated thickness with matching filler.

$\mathrm{CR}=$ Cold rolled $40 \%$

Exposure: 47.3 weeks in water containing $36 \mathrm{ppm}$ oxygen, followed by 20.6 weeks in water containing 8 ppm oxygen.

Studies by Clarke et al. ${ }^{10)}$ suggest that alloy 690 is not immune to cracking in very high oxygen environments (i.e., $36 \mathrm{ppm}$ oxygen) at $289^{\circ} \mathrm{C}$. However, the microstructure of the material tested was not typical of wrought alloy 690. A subsequent series of tests repeated by Clarke and McIlree $^{11)}$ using material with well defined heat treatments, did not reveal cracking, although one of the welded specimens had a defect in the filler material. It could not be ascertained whether this defect was a pre-existing shrinkage void or had been caused by the exposure to the environment. Since previous tests had not indicated any susceptibility to cracking by the filler, it seems likely that the observed defect was due to shrinkage during welding. The results of these stress corrosion tests are shown in Table 12.

The stress corrosion tests in oxygen containing water in the presence of crevices suggest that alloy 690 is highly resistant to cracking under these conditions. However, in view of the findings by Clarke $^{10)}$, alloy 690 should not be regarded as immune in oxygen-saturated high temperature solutions. It seems extremely unlikely, however, that oxygen saturated solutions would ever be encountered in operating boiling water (BWR) or pressurized water (PWR) reactors.

\subsection{High Temperature Water with Low Oxy- gen Content}

Alloy 690 has been extensively tested for resistance to stress corrosion cracking in high temperature low oxygen water using alloy 600 as the control. The following test environments were employed:

1. Deaerated $\mathrm{pH} 10$ water, $316^{\circ} \mathrm{C}$ (48 weeks) and $360^{\circ} \mathrm{C}$ ( 60 weeks).

2. Deaerated $\mathrm{pH} 10$ water $+60 \mathrm{ppm}$ $\mathrm{Na}_{2} \mathrm{HPO}_{4}, 326^{\circ} \mathrm{C}, 96$ weeks.

3. Deaerated water, unadjusted $\mathrm{pH}, 316^{\circ} \mathrm{C}$, 48 weeks.

4. Deaerated water, unadjusted $\mathrm{pH}+\mathrm{Pb}$, $316^{\circ} \mathrm{C}, 18$ weeks.

For the $316^{\circ} \mathrm{C}$ tests in deaerated $\mathrm{pH} 10$ water, the solution was prepared by deaerating distilleddeionized water (resistivity $>1 \mathrm{M} \Omega-\mathrm{cm}$ ) with argon in the closed autoclave by three alternate pressurizing/aspirating cycles. This was followed by bubbling with argon for 2 hours. The autoclave was sealed with 1 atmosphere of argon in the headspace. This procedure gives an oxygen content of about $20 \mathrm{ppb}$. The $\mathrm{pH}$ was adjusted with $\mathrm{NH}_{4} \mathrm{OH}$.

The $360^{\circ} \mathrm{C}$ tests in deaerated $\mathrm{pH} 10$ water were carried out using a refreshed autoclave. The test solution was distilled-deionized water adjusted to pH 10 with $\mathrm{NH}_{4} \mathrm{OH}$ and deaerated with hydrogen gas and catalyzed $\mathrm{N}_{2} \mathrm{H}_{4}\left(35 \% \mathrm{~N}_{2} \mathrm{H}_{4}\right.$ with organic catalyst). The water was pumped from a $190 l$ (50 gal) holding tank to the autoclave at a rate of $1.14 \mathrm{l} / \mathrm{h}(0.3 \mathrm{gal} / \mathrm{h})$. This procedure again yields oxygen contents of $<20 \mathrm{ppb}$.

For tests in deaerated pH 10 water with phosphate, deaeration was carried out by bubbling with nitrogen for 3.5 hours and addition of $0.65 \mathrm{ml} / l$ of hydrazine $\left(\mathrm{N}_{2} \mathrm{H}_{4} \cdot \mathrm{H}_{2} \mathrm{O}\right)$. Sodium hydroxide was used to adjust the $\mathrm{pH}$ to 10 . This procedure 
Table 13. Stress corrosion tests in deaerated $\mathrm{pH} 10$ water at $316^{\circ} \mathrm{C}$ to evaluate the effects of heat treatment, cold work, welding and crevices

\begin{tabular}{|c|c|c|c|c|c|}
\hline Alloy & $\begin{array}{l}\text { Heat } \\
\text { treatment } \\
\text { code }\end{array}$ & $\begin{array}{l}\text { Number of } \\
\text { specimens } \\
\text { (Number } \\
\text { of heats) }\end{array}$ & $\begin{array}{c}\text { Test } \\
\text { duration } \\
(w k)\end{array}$ & $\begin{array}{l}\text { Number of } \\
\text { specimens } \\
\text { cracked/number } \\
\text { destructively } \\
\text { examined }\end{array}$ & $\begin{array}{l}\text { Maximum } \\
\text { depth of } \\
\text { attack } \\
(\mathrm{mm})\end{array}$ \\
\hline \multirow[t]{8}{*}{$690^{*}$} & MA & $2(1)$ & 48 & $0 / 2$ & 0 \\
\hline & $\mathrm{MA}+\mathrm{L}$ & $2(1)$ & 48 & $0 / 2$ & 0 \\
\hline & $\mathrm{MA}+\mathrm{A}_{1}$ & $2(1)$ & 48 & $0 / 2$ & 0 \\
\hline & $\mathrm{CR}$ & $2(1)$ & 48 & $0 / 2$ & 0 \\
\hline & $\mathrm{A}_{1}+\mathrm{L}$ & $2(1)$ & 48 & $0 / 2$ & 0 \\
\hline & $\mathrm{A}_{3}+\mathrm{L}$ & $2(1)$ & 48 & $0 / 2$ & 0 \\
\hline & $A_{2}+W(12.7)$ & $2(1)$ & 18 & $0 / 2$ & 0 \\
\hline & $\mathrm{A}_{2}+\mathrm{W}(25.4)$ & $2(1)$ & 18 & $0 / 2$ & 0 \\
\hline \multirow[t]{5}{*}{600} & $\mathrm{CR}+\mathrm{A}_{1}$ & $2(1)$ & 48 & $0 / 2$ & 0 \\
\hline & $\mathrm{MA}+\mathrm{CR}$ & $2(1)$ & 18 & $1 / 2$ & 2.79 \\
\hline & & $2(1)$ & 48 & $0 / 2$ & 0 \\
\hline & $\mathrm{A}_{1}+\mathrm{L}$ & $2(1)$ & 48 & $0 / 2$ & 0 \\
\hline & $\mathrm{A}_{3}+\mathrm{L}$ & $2(1)$ & 48 & $0 / 2$ & 0 \\
\hline
\end{tabular}

Double u-bend (crevice) test specimens

Code: $\mathrm{MA}=$ mill annealed

$\mathrm{CR}=$ cold rolled $40 \%$

$\mathrm{A}_{1}=1 \mathrm{~h} @ 1093^{\circ} \mathrm{C} / \mathrm{WQ}$

$\mathrm{A}_{2}=1 \mathrm{~h} @ 1150^{\circ} \mathrm{C} / \mathrm{WQ}$

$\mathrm{A}_{3}=1 \mathrm{~h} @ 1205^{\circ} \mathrm{C} / \mathrm{WQ}$

$\mathrm{L}=2 \mathrm{~h} @ 650^{\circ} \mathrm{C} / \mathrm{AC}$

$\mathrm{W}$ (thickness, $\mathrm{mm})=$ manual gas tungsten-arc welded at indicated thickness with matching filler

* Heat Y24A7L

Table 14. Stress corrosion tests in deaerated $316^{\circ} \mathrm{C}$ water (unadjusted $\mathrm{pH}$ ) to evaluate the effects of heat treatment, welding and the presence of crevices

\begin{tabular}{|c|c|c|c|c|c|}
\hline Alloy & $\begin{array}{l}\text { Heat } \\
\text { treatment } \\
\text { code }\end{array}$ & $\begin{array}{l}\text { Number of } \\
\text { specimens } \\
\text { (Number } \\
\text { of heats) }\end{array}$ & $\begin{array}{c}\text { Test } \\
\text { duration } \\
(w k)\end{array}$ & $\begin{array}{l}\text { Number of } \\
\text { specimens } \\
\text { cracked/number } \\
\text { destructively } \\
\text { examined }\end{array}$ & $\begin{array}{l}\text { Maximum } \\
\text { depth of } \\
\text { attack } \\
(\mathrm{mm})\end{array}$ \\
\hline \multirow[t]{9}{*}{$690 *$} & MA & $4(1)$ & 48 & $0 / 4$ & 0 \\
\hline & $\mathrm{MA}+\mathrm{L}$ & $4(1)$ & 48 & $0 / 4$ & 0 \\
\hline & $\mathbf{A}_{1}$ & $4(1)$ & 48 & $0 / 4$ & 0 \\
\hline & $\mathrm{A}_{2}$ & $6(1)$ & 48 & $0 / 6$ & 0 \\
\hline & $\mathrm{A}_{1}+\mathrm{L}$ & $4(1)$ & 48 & $0 / 4$ & 0 \\
\hline & $\mathrm{A}_{3}+\mathrm{L}$ & $4(1)$ & 48 & $0 / 4$ & 0 \\
\hline & CR & $4(1)$ & 48 & $0 / 4$ & 0 \\
\hline & $A_{2}+W(12.7)$ & $4(1)$ & 48 & $0 / 4$ & 0 \\
\hline & $A_{2}+W(25.4)$ & $2(1)$ & 48 & $0 / 2$ & 0 \\
\hline \multirow[t]{3}{*}{600} & MA & $4(1)$ & 48 & $1 / 4$ & 0.05 \\
\hline & $\mathrm{A}_{1}$ & $4(1)$ & 48 & $1 / 4$ & 0.12 \\
\hline & $\mathrm{A}_{1}+\mathrm{L}$ & $4(1)$ & 48 & $0 / 4$ & 0 \\
\hline
\end{tabular}

Double u-bend (crevice) test specimens

Code: $\quad \mathrm{MA}=$ mill annealed

$\mathrm{CR}=$ cold rolled $40 \%$

$\mathrm{A}_{1}=1 \mathrm{~h} @ 1093^{\circ} \mathrm{C} / \mathrm{WQ}$

$\mathrm{A}_{2}=1 \mathrm{~h} @ 1150^{\circ} \mathrm{C} / \mathrm{WQ}$

$\mathrm{A}_{3}=1 \mathrm{~h} @ 1205^{\circ} \mathrm{C} / \mathrm{WQ}$

$\mathrm{L}=2 \mathrm{~h} @ 650^{\circ} \mathrm{C} / \mathrm{AC}$

$\mathrm{W}($ thickness, $\mathrm{mm})=$ manual gas tungsten-arc welded at indicated thidkness with matching filler 
Table 15. Supplementary higher temperature $\left(360^{\circ} \mathrm{C}\right)$ stress corrosion tests of Alloy $690^{*}$ U-bends in deaerated $\mathrm{pH} 10$ water to evaluate the effects of heat treatment

\begin{tabular}{lcccc}
\hline $\begin{array}{c}\text { Heat } \\
\text { treatment } \\
\text { code }\end{array}$ & $\begin{array}{c}\text { Number of } \\
\text { specimens } \\
\text { (Number } \\
\text { of heats) }\end{array}$ & $\begin{array}{c}\text { Test } \\
\text { duration } \\
\text { (wk) }\end{array}$ & $\begin{array}{c}\text { Number of } \\
\text { specimens } \\
\text { cracked/number } \\
\text { destructively } \\
\text { examined }\end{array}$ & $\begin{array}{c}\text { Maximum } \\
\text { depth of } \\
\text { attack } \\
\text { (mm) }\end{array}$ \\
\hline $\mathbf{M}$ & $4(2)$ & 60 & $0 / 4$ & 0 \\
$\mathbf{A}_{4}$ & $2(1)$ & 60 & $0 / 2$ & 0 \\
$\mathrm{~A}_{4}+\mathbf{L}_{4}$ & $2(1)$ & 60 & $0 / 2$ & 0 \\
\hline
\end{tabular}

Code: $\mathrm{M}=0.5 \mathrm{~h} @ 1010^{\circ} \mathrm{C} / \mathrm{AC}$

$\mathrm{A}_{4}=1 \mathrm{~h}$ @ $1120^{\circ} \mathrm{C} / \mathrm{WQ}$

$\mathrm{L}_{4}=1 \mathrm{~h} @ 675^{\circ} \mathrm{C} / \mathrm{AC}$

* Heats NX 4458H, NX 4460H

gives an oxygen content of $10 \sim 20 \mathrm{ppb}$.

Solutions with unadjusted $\mathrm{pH}$ were prepared by pressurizing/aspirating with argon followed by steaming some of the solution from the autoclave. This procedure yields oxygen contents between 0 and $5 \mathrm{ppb}$. In the preparation of the unadjusted $\mathrm{pH}$ solutions containing lead added as an impurity ( $10 \mathrm{~g}$ lead powder $/ 1.8 l$ of water), the steaming step was omitted, and the autoclave was sealed with one atmosphere of argen in the headspace. This technique yields an oxygen content of about 20 ppb.

Alloy 690 resisted cracking in all the deaerated water tests employed. In deaerated water tests No. 1 and No. 3, a wide range of heat treatments, cold work, welding, and the presence of crevices were evaluated. As shown in Tables 13 and 14, none of these variables appeared to impair the stress corrosion cracking resistance of alloy 690 . Also, in test No. 2, increasing the test temperature to $360^{\circ} \mathrm{C}$ and the exposure time to 60 weeks did not produce cracking in alloy 690 (Table 15).

These results can be summarized as showing that alloy 690 does not appear to be susceptible to stress corrosion cracking in the low oxygen waters which Coriou et al. ${ }^{12)}$ and Copson et al. ${ }^{97,13)}$ have shown to be capable of producing intergranular penetration in other high nickel alloys.

\subsection{Other Environments}

In addition to the stress corrosion tests of alloy 690 already described, there have been two other evaluations carried out. In a study by Vermilyea ${ }^{14)}$, alloy 690 was tested at a controlled electrochemical potential of 0 volts (standard hydrogen electrode) in a pH $2.5 \mathrm{H}_{2} \mathrm{SO}_{4}$ solution at $289^{\circ} \mathrm{C}$. In the other, Hammond et al. ${ }^{15)}$ evaluated alloy 690 in a steam environment containing $10 \mathrm{ppm}$ chloride and $20 \mathrm{ppm}$ oxygen, with the temperature being cycled between 280 and $430^{\circ} \mathrm{C}$. Alloy 690 exhibited com- plete resistance to stress corrosion cracking in both of these environments. ${ }^{14,15}$ )

\section{Summary}

INCONEL alloy 690 is a stable austenitic highchromium nickel-base alloy which represents a useful addition to the corrosion resistant $\mathrm{Ni}-\mathrm{Cr}$ $\mathrm{Fe}$ alloy family. Its high chromium content ensures a high corrosion resistance in oxidizing acids and in flowing high temperature water environments, while its high nickel content provides a high resistance to chloride stress corrosion cracking. The low carbon content of alloy 690 prevents sensitization by chromium depletion in the vicinity of precipitated grain boundary carbides. The alloy appears to be highly resistant to stress corrosion cracking in various aqueous environments at temperatures encountered in nuclear steam generators.

\section{Acknowledgements}

The authors wish to thank A. R. Mcllree and R. E. Warringer for their help with some of the experimental work reported in this paper.

(Received August 22, 1978)

\section{References}

1) J. W. Schultz and H. F. Merrick: Metallurgical Transactions, 3, 2479 (1972).

2) "Preliminary Data on the Engineering Propertics of Alloy 690", The International Nickel Co., Inc., New York.

3) M. Hecht et al., in "The Corrosion Handbook" (ed., H. H. Uhlig), p. 530, John Wiley \& Sons, Inc., New York, (1963).

4) NACE Technical Practices Committee Report, "Procedures for Quantitative Removal of Oxide Scales Formed in High Temperature Water and Steam", Materials Protection, p. 69, July, 1967. 
5) N. Pessall, A. B. Dunlap and D. W. Feldman: CORROSION, 33, 130 (1977).

6) G. F. Taylor: "Corrosion Monitoring in CANDU Nuclear Generating Stations", paper No. 119, presented at CORROSION/77NACE, March, (1977).

7) A. R. McIlree and H. T. Michels, CORROSION, 32, 60 (1977).

8) A. J. Sedriks, S. Floreen and A. R. Mcllree: CORROSION, 32, 157 (1976).

9) H. R. Copson and G. Economy: CORROSION, 24, 55 (1968).

琹 10) W. L. Clarke et al.: "Corrosion Problems in Energy Conversion and Generation", The Elec- trochemical Society, Princeton, NJ, p. 410, (1974).

11) W. L. Clarke and A. R. Mcllree: General Electric Co., Valecitos, CA, private communication, January, 1977.

12) H. Coriou et al.: CORROSION, 22, 280, (1966).

13) H. R. Copson and S. W. Dean: CORROSION, 21, 3 (1965).

14) D. A. Vermilyea: CORROSION, 31, 421 (1975).

15) J. P. Hammond et al.: Materials Performance, p. 41, Nov. (1975). 